\title{
A Multicarrier PWM Technique for Five Level Inverter Connected to the Grid
}

\author{
M. Khanfara ${ }^{1}$, R. El Bachtiri ${ }^{2}$, M.Boussetta ${ }^{3}$, K. El Hammoumi ${ }^{4}$ \\ ${ }^{1,2,4}$ CED STI, FST, PERE Laboratory EST-USMBA, Fez, Morocco \\ ${ }^{3}$ D FSDM, LESSI Laboratory, EST-USMBA, Fez, Morocco
}

\begin{tabular}{l}
\hline Article Info \\
\hline Article history: \\
Received May 16, 2018 \\
Revised Aug 10, 2018 \\
Accepted Aug 24, 2018 \\
\hline
\end{tabular}

\section{Keyword:}

Five level inverter

MCPWM control

PPFC

Total Harmonic Distortion

\section{Corresponding Author:}

M. Khanfara Author, CED STI, FST, PERE laboratory, EST-USMBA, Fez, Morocco.

Email: 1snt1@ccu.edu.tw

\begin{abstract}
In this paper, a three-phase multilevel cascaded H-bridge inverter is developed for injecting renewable power energy into the grid through a filter. The main contribution of this work is to reduce the total harmonic distortion (THD) by using a passive filter and to enhance the output voltages by adopting a multicarrier pulse width modulation (MCPWM). The simulation results affirm a good performance of the proposed multicarrier PWM control using a three-phase five-level inverter. The proposed inverter is tested as well as the THD and the spectral analysis of the output voltage are calculated using Simulink/Matlab software.
\end{abstract}

Copyright $@ 2018$ Institute of Advanced Engineering and Science. All rights reserved.

\section{INTRODUCTION}

The multilevel inverter uses highly efficient converter types for medium and high voltage and high power applications [1] It has interesting features like high-voltage capability, reduced power device stress, near-sinusoidal output, or even no output filter which makes them suitable for high power applications [2]. Multilevel inverters are used for AC transmission systems, clean energy sources, power supplies without disruption, electrical conduction and active power filters. [3].

Several technics are proposed in literature. An electromagnetic disturbance problem in common mode using five-level inverter [4]. A seven-level inverter supplying with a DC and based on the real-time control using an artificial algorithm control [5], [6].

Many topologies treated such us a cascaded H-Bridge (CHB) and the NPC (neutral point) which are widely usable for industrial applications. [7], [8], an intelligent technique is analyzed with NPC inverter in [9]. Furthermore, different control techniques applied to the inverter to reduce the switching losses [10].

The injection of photovoltaic power into the grid increases the risk of harmonic pollution and deterioration of the voltage waveform. Indeed, PV systems use static converters especially inverters that generate harmonics. These produce current harmonics that create more losses of or malfunction in the network and consumer [11].

Due to the prospect of good power quality on the power grid, harmonics and technical requirements IEC 1000-3-2, IEEE 519 (USA), AS 2279, are used to limit the level of THD [12]. In addition, the EN50160 standard, which defines all the control parameters and the quality of an electrical distribution network, particularly with regard to electrical disturbances, requires a THD $<4 \%$. The design of multi-level inverters allows the harmonic distortion of the output waveform to be reduced without increasing the switching 
frequency. Previous studies have been the main focus on three stage, the number of voltage levels is limited by voltage unbalance problems, the majority of multilevel inverters were presented in [13].

Multilevel voltage source inverters (MVSI) are used in high power DC to AC power conversion applications. MVSI gives various advantages such the ability to manage a higher DC link voltage, and to reduce harmonics distortion [14]. Multilevel inverters have benefits such as low switching frequency, low harmonic distortion and high power conversion. [15].

A hybrid switching technique using pulse amplitude modulation (PAM) dedicated for NPC inverter in order to eliminate harmonic [16] A single-phase sensor-less Packed U-Cell (PUC) inverter has been introduced by Sandeep et al [17], to generate five-level voltage using an adequate voltage control based on redundant switching states which is integrated into switching process.

Recent researches have been interested in filter for a transformer-less grid-tied converter using (PWM). Rohit G. Ramteke and U. V. Patil gave various topologies throught a comparative study of passive filters was proposed to reduce the total inductance value, without increasing capacitive reactive power [18].

PWM is a non-linear process that creates harmonics over the entire frequency spectrum. Depending on the properties of the reference signal and depending on its interaction with the modulator, the DC component or the even harmonics may be zero.

A sliding mode current controller (SMCC) is applied for grid-connected inverter with fixed frequency (PWM) [19], and F. Sebaaly et al. show a closed-loop space vector modulation (SVM) sliding mode controller (SMC) for a 3-point UPS (3L-NPC) connected to a neutral point connected to the network [20]. The performance of a modulator is characterized by its ability to generate a signal close to the reference signal. Various measurements make it possible to evaluate the distance between the input and output signals of a modulator.

In this work, we proposed a multicarrier PWM control and some simulations using a three-phase five-level inverter connected to the grid. To improve the output voltages, we have used a constant switching frequency MPWM. To eliminate the harmonics effect we have used a LC filter. We have calculated spectrum and THD, both of which are necessary to assess the quality of the output voltage and the current of the inverter. The line voltage and current waveforms are obtained by simulation using MATLAB/SIMULINK.

\section{STUDIED SYSTEM}

The Figure 1 consists a DC source connected in cascaded to an H-bridge five-level voltage inverter, tied to the grid through a filter to eliminate the harmonic.

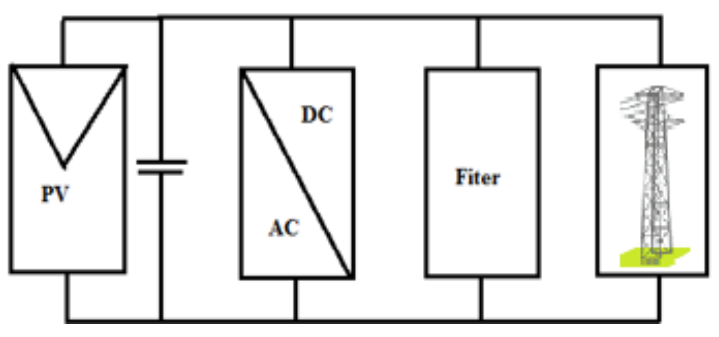

Figure 1. Block diagram of the system

\section{MULTILEVEL INVERTER}

Several scientific research about the various topologies of multi-level converters has been published. Out of all of these topologies there is one that is based on the use of partial inverters (full bridge cells) in a series on each phase. This particular model has two main features: simplicity of configuration, whatever the number of levels of the desired voltage at the output of the converter; and the existence of standard inverter modules on the market. However, it requires galvanic power sources separated from one another, which further limits its industrial expansion. In [21] deals with the simulation and implementation of nine level inverter system. The inverter used in this study is a cascaded H-bridge five-levels with separate DC composed of two H-bridge cells, fed by a DC source. Each of the cells has four semiconductor IGBT switches mounted in parallel with an inversed diode. IGBT control voltage of the inverter is obtained by comparing a reference or modulating wave, generally sinusoidal (the signal to be synthesized) with a generally triangular carrier. The circuit configuration of our inverter and the waveform are presented in Figure 2. The five-level inverter output voltage in Figure 3. For this inverter, two single-phase full-bridge cells and two independent power supplies are used. 


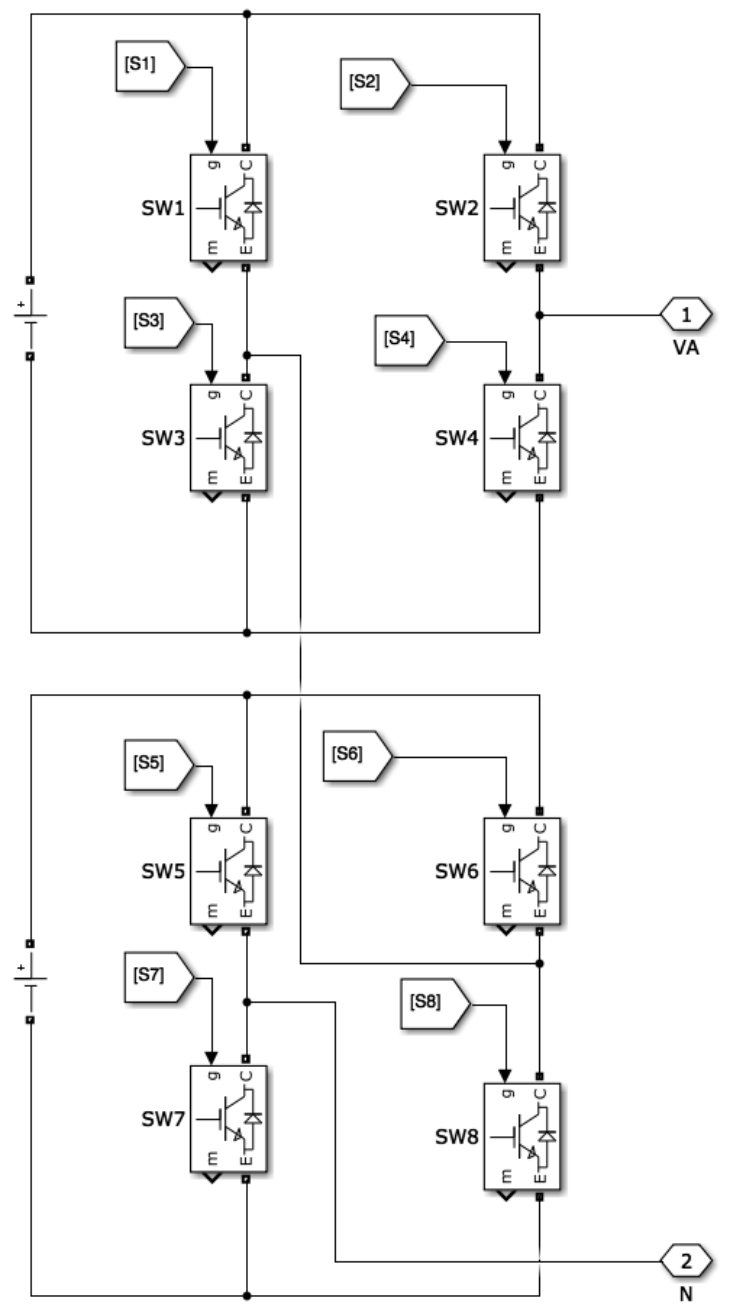

Figure 2 Five-level inverter using DC

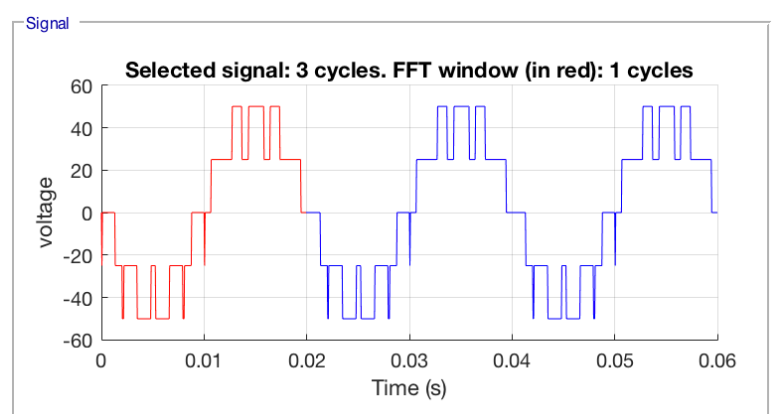

Figure 3. Five-level inverter waveform

The inverters are supplied with continuous voltages having identical values. E1 and E2 are the DC voltage provided from two independent DC sources generator. The gate represents the gating signals used for controlling the switches.

The simplest way to generate a PWM signal is to compare the message signal to a triangular or ramp waveform. The output voltage is raised when the input is greater than the triangular waveform neither when 
the input is lower. Thus, the two basic blocks required for PWM are a triangular-waveform generator and a comparator as shown in Figure 4.

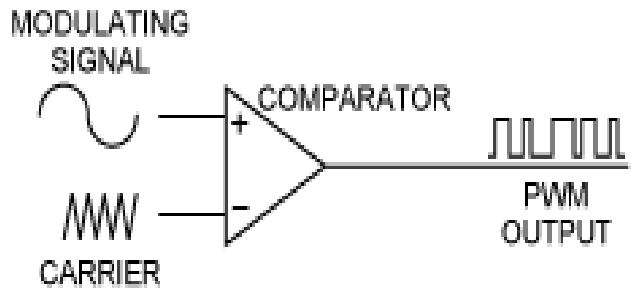

Figure 4. A comparator configuration to produce a PWM signal

\section{INVERTER CONTROL}

In this study, a five-level inverter will be controlled by MCPWM in order to improve the performance of our system and mitigate the THD. Each leg is controlled by comparing a reference signal with its own triangular carrier. For this work it is necessary to use four carriers.

PWM is widely used for controlling conventional inverters. It is also the modulation strategy most commonly used in multi-level inverters called sinusoidal modulation. It consists of comparing a reference or modulating wave, generally sinusoidal (the signal to be synthesized) with a generally triangular carrier.

The output signal changes state at each intersection of the reference signal and the carrier. In this modulation technique, with the MCPWM implemented and the triangular multicarrier signals set, we use the different carriers to construct all the necessary commands for all the switches. In this technique, the reference is compared constantly to each of the triangular signals. If the reference is greater than a triangular signal, the output signal is 1 . In this case, the switch corresponding to this modulation is active. However, if the reference is less than a triangular signal, then the output signal changes state.

In this case, we have four triangular signals that have the same frequency and the same amplitude. Figure 5 shows a reference and four triangular signal. And demonstrate the fixed switching frequency in each cycle.

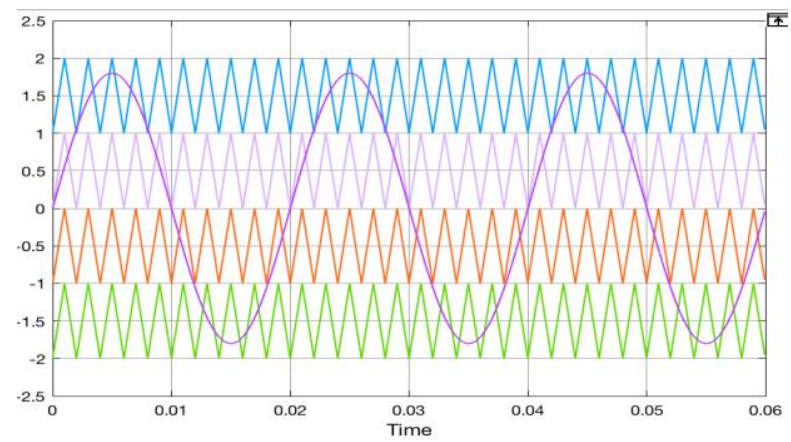

Figure 5. Carrier arrangement for MCPWM strategy of single five-level inverters

The proposed method ensures a low switching frequency and fixed functionality of the five-level inverter at low switching losses and high efficiency compared to other topologies. The PWM are computed to minimize current harmonics and pulsating torques. The method will be applied on ARDUINO MEGA in order to confirm experimentally this method.

$\mathrm{A}_{\mathrm{m}}=0.8 \mathrm{~A}_{\mathrm{C}}=2$ are amplitude of modulating and carrier signal respectively, $\mathrm{f}_{\mathrm{m}}=50 \mathrm{~Hz}$ and $\mathrm{f}_{\mathrm{c}}=500 \mathrm{~Hz}$ are frequency of modulating and carrier signal.

\section{SIMULATION RESULTS}

\subsection{Five-levels Inverter}


Figure 6 shows the proposed schemes in Matlab\&Simulink software of the studied three phase Fivelevel inverter.

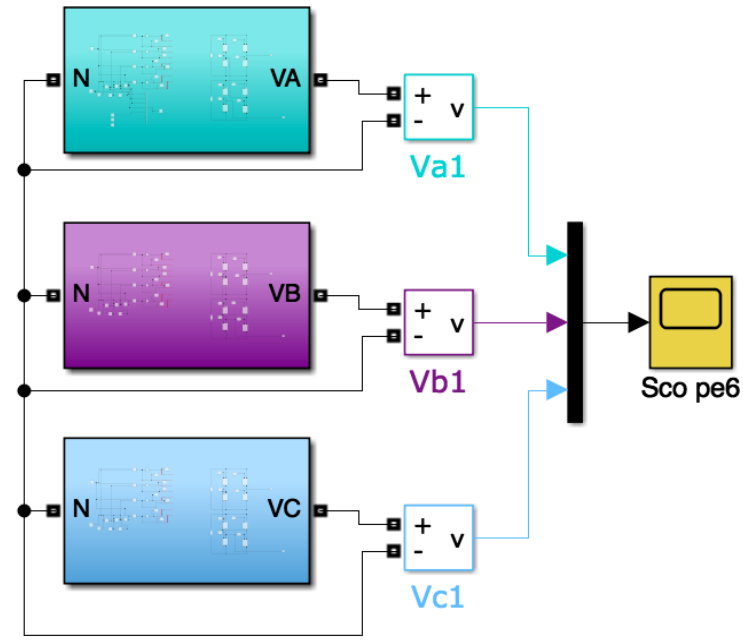

Figure 6. Three-phase 5-level inverter

The references signals are phase shifted by 180 degrees. The triangular signals are modulated respectively with:

$A_{m}=0.8$ and $A_{C}=2 . f_{m}=50 H z$ and $f_{c}=500 \mathrm{~Hz}$ Are frequency of modulating and carrier signal. as shown in Figure 7. As we see in Figure 8 the output voltage of Three-phase five-level inverter is alternative. The purpose of our work is performed in advance to have a practical sine wave output voltage.

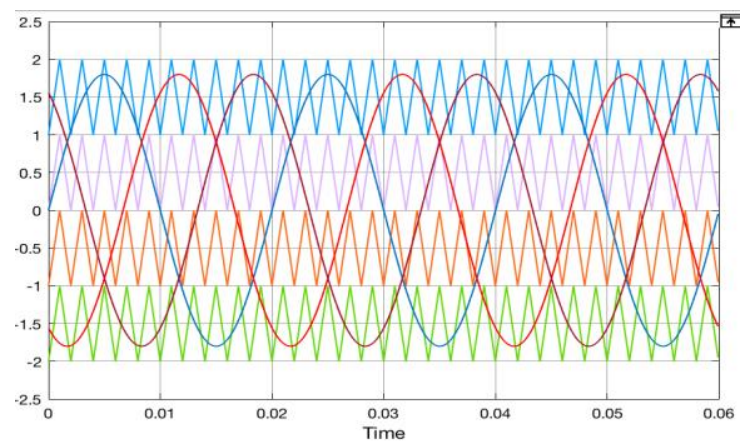

Figure 7. Carrier arrangement for MCPWM strategy of three phase five-level inverter

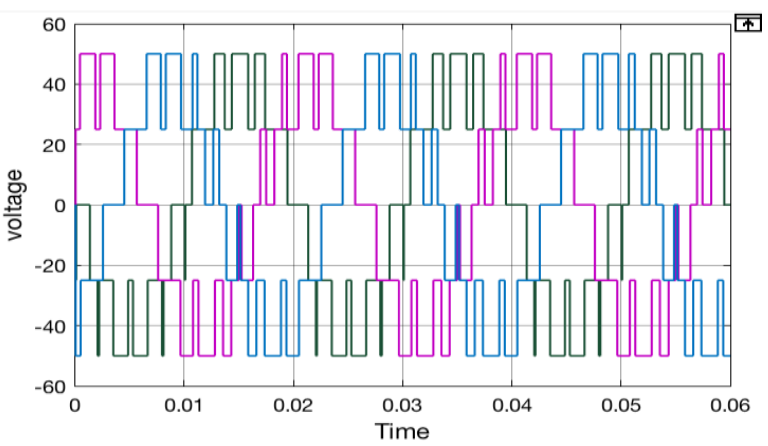

Figure 8. Three-phase line voltage of inverter

\subsection{Spectral Analysis of the Phase Line Voltage}


Figure 9 gives the THD value of output voltage and the magnitude of the fundamental frequency. The voltage waveform at fundamental frequency of $50 \mathrm{~Hz}$ and switching frequency of $500 \mathrm{~Hz}$ is obtained for the proposed MCPWM control.

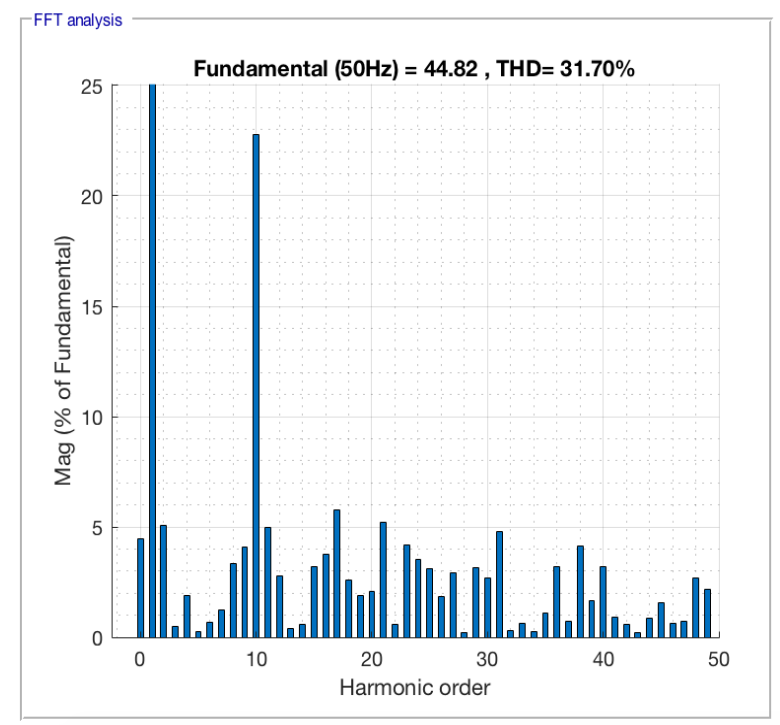

Figure 9. FFT analysis of a phase line voltage of inverter

The (THD) was chosen to be evaluated using the filter. Fast Fourier Transform (FFT) is applied to obtain the spectrum of the output voltage to find out THD. From the FFT analysis of the below result, it can be seen that the THD remains over $31.70 \%$ due to 10 th harmonic order. Consequently, we thought that a lowpass filter could solve the problem and allow us to achieve our goal while still maintaining a THD that satisfies the norm EN50160. For alleviating the impact of this harmonics components and reduce the harmonics, we introduced a low-pass filter which is designed in Figure 10.

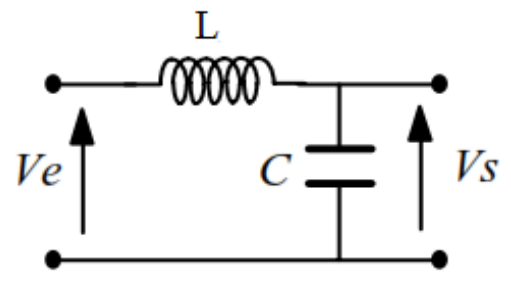

Figure 10. Low pass filter

To eliminate or reduce all type of harmonic frequencies over a threshold frequency, mostly we use a low pass filter in order to block the unwanted harmonics and allow a certain frequency range to be transmitted. We chose a LC filter as shown in Figure 11 in order to have a better attenuation, reduce the losses and cost [22], [23]. 


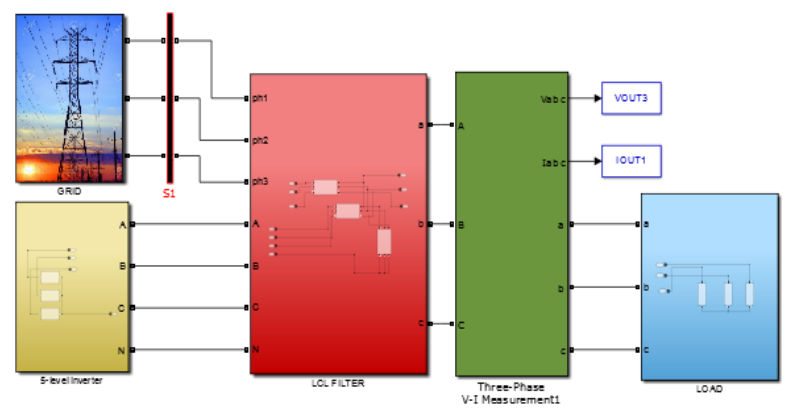

Figure 11. Five-level inverter with low-pass LC filter

\subsection{Low-pass Filter}

The transfer function of this low-pass LC filter is:

$$
\begin{aligned}
& H(j \omega)=\frac{\frac{1}{J C \omega}}{\frac{1}{J C \omega}+j l \omega}=\frac{1}{1-l C \omega^{2}} \\
& f_{c}=\frac{1}{2 \pi \cdot \sqrt{L_{f} C_{f}}}
\end{aligned}
$$

The simulation result of the system connected to grid feeds a load as shown in Figure 11. The inverter can be configured as a standalone supplying a load, such as the system presented in this paper. The utility of the grid is defined as the infinite bus bar, which has a constant voltage and frequency. The grid synchronization is very necessary for the grid connected inverter, it can be achieved by using a passive filter.

In this case, a linear load will be supplied, a passive filter is the simplest and cheapest solution of all, and it uses passive elements to improve the current flow. LCL filter is used to attenuate the deformation created by the harmonics particular the $3^{\text {rd }}$ one, this has the effect to bring it back into phase with the tension. The stiffness of the rising edges of the current is attenuated by the inductance which storing some energy and then redistributing it.

The LCL filter is used to mitigate harmonics produced by the inverter as shown in Figure 11 is placed between the grid and the inverter, in this case, L takes the role of grid inductor and LC takes the passive filer of the inverter

As shown in Figure 12 the output current is sinewave and in phase. The MCPWM strategy is applied for a three-phase cascaded H-bridge five-level inverter connected to grid. The FFT spectrum give the magnitude of the fundamental and the value of harmonic distortion output voltages and current which supplied a linear load.

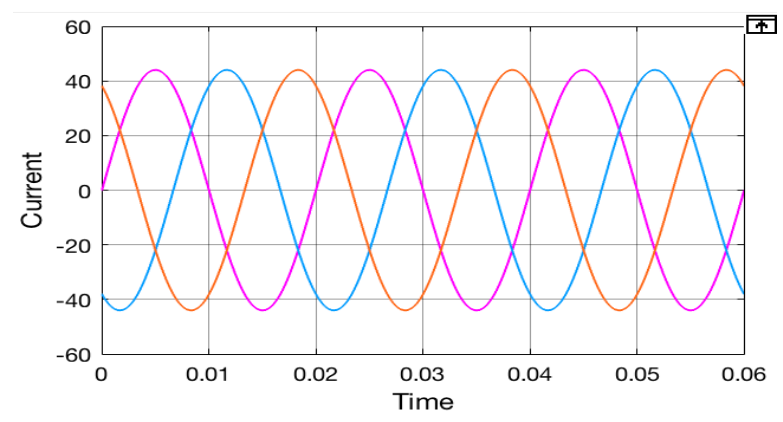

Figure 12. Output current of grid connected inverter supplied a linear load

We notice that the voltage and current fed to the grid by supplying a resistive load is stable since they are at the same phase as shown in Figure 13. As shown in Figure 14 the LCL filter eliminates all 
frequencies above the fundamental harmonic but there is an important reduction in THD from $31.70 \%$ to $0.07 \%$. Finally, as we may have expected this method block unwanted harmonics and allows the grid frequency to be transmitted.

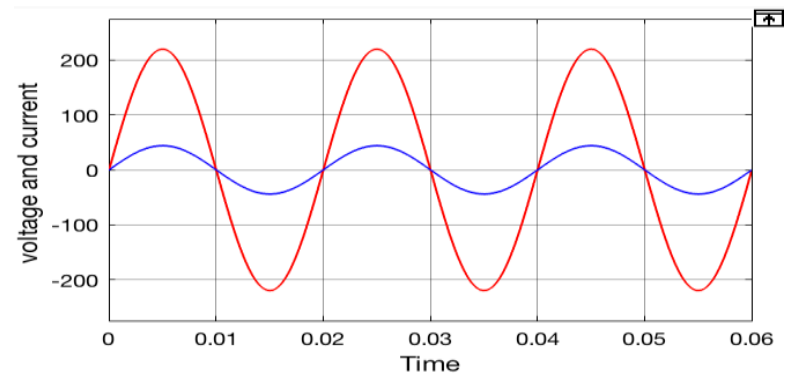

Figure 13. Output current and voltage of grid connected inverter supplied a linear load
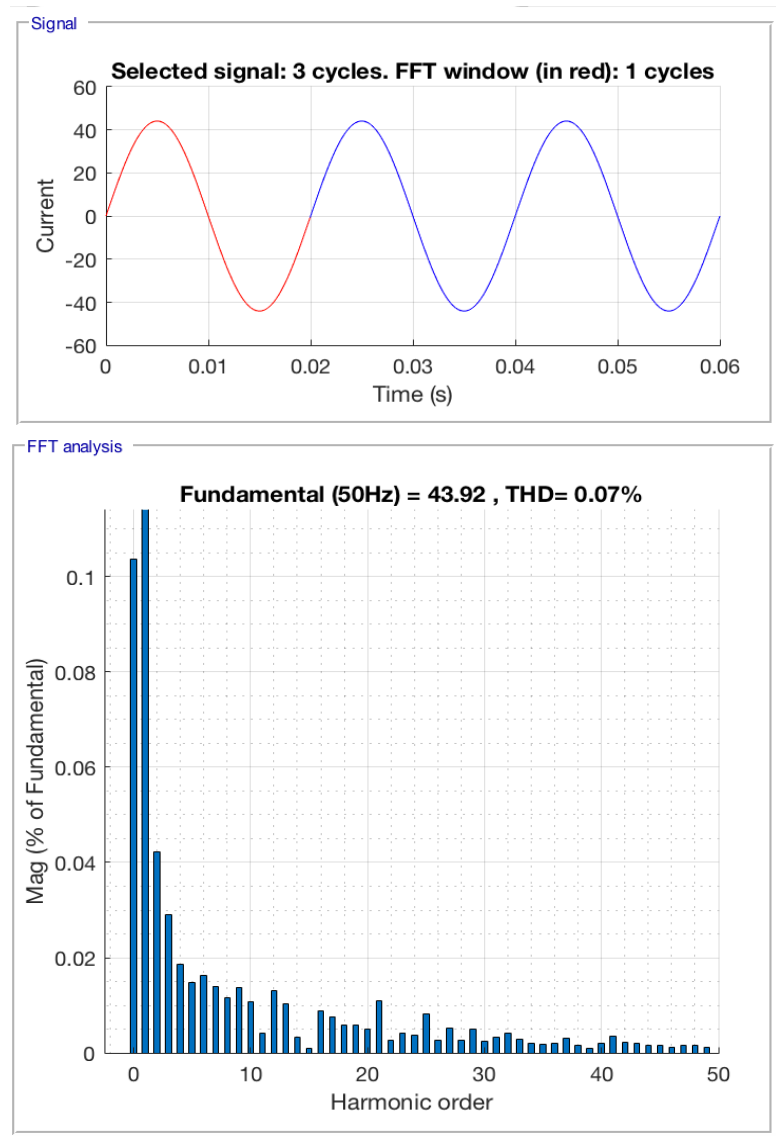

Figure 14. FFT analysis of output current of grid connected inverter supplied a resistive load

\section{RESULTS AND DISCUSSIONS}

The MCPWM strategy is applied for a three-phase cascaded H-bridge five-level inverter, connected to the grid through a passive filter. The results shown that the current harmonic are eliminated by using an LCL filter and gives a better THD which reduced from $31.70 \%$ to $0.07 \%$ compared to the current THD of a quasi-resonant inverter configuration with filter is about $12.9 \%$ [24], and two different control are applied to three phase inverter, their THD about $3.31 \%, 1.36 \%$ respectively [25], we notice that our proposed configuration thechnique gives a good performance regarding to that of the two technique. The aim of this work is to improve the current flow attenuating the deformation created by the harmonics and make the 
current and tension of grid in phase. In Figure 13 the voltage and current have produced a sine form and that satisfies the EN50160 norm.

\section{CONCLUSION}

In this paper, the proposed configuration gives a better harmonic performance and selection of suitable switching frequency in the MCPWM strategy. We have modeled and simulated a three phase fivelevel inverter connected to the grid and supplied a linear load by using MCPWM technique. We have used a low-pass filter. The simulation results show that the MCPWM technique enhances the fundamental output voltage and eliminated selected harmonics but given a THD in the order of $31.70 \%$. Thus a passive filter has been used to eliminate all harmonics and gives a better THD of $0.07 \%$. With the low-pass filter the voltage and current have produced a sinewave form and satisfying the EN50160 norm.

\section{REFERENCES}

[1] S. Kouro, M. Malinowski, K. Gopakumar, J. Pou, L.G. Franquelo, Bin Wu, J. Rodriguez, M.A. Perez and J.I. Leon, "Recent Advances and Industrial Applications of Multilevel Converters", IEEE Transactions on Industrial Electronics, vol.57, n.8, pp.2553-2580, Aug. 2010.

[2] S.Kouro, P.Lezana, Mauricio, Angulo, and J.Rodríguez, "Multicarrier PWM with DC-link ripple feedforward compensation for multilevel inverter", IEEE Transactions on Power Electronics, vol.23, n.1, pp.52-59, Jan. 2008

[3] J. Rodriguez, B. Wu, S. Bernet, J.O. Pontt and S. Kouro, "Multilevel voltage-source-converer topologies for industrial medium-voltage drives", IEEE Transactions on Industrial Electronics, Vol.54, n.6, pp.2930-2945, Dec. 2007.

[4] X. Guo, R. He, and M. Narimani, "Modeling and Analysis of New Multilevel Inverter for Solar Photovoltaic Power Plant," International Journal of Photoenergy, vol. 2016, pp. 1-8, 2016.

[5] F. Khoucha, K. Marouani, M. Benbouzid, A. Kheloui, and A. Mamoune, "A 7-Level Single DC Source Cascaded HBridge Multilevel Inverter with a Modified DTC Scheme for Induction Motor-Based Electric Vehicle Propulsion," International Journal of Vehicular Technology, vol. 2013, pp. 1-9, 2013.

[6] L. Wang, C. Mao, D. Wang, J. Lu, J. Zhang, and X. Chen, "A Real-Time and Closed-Loop Control Algorithm for Cascaded Multilevel Inverter Based on Artificial Neural Network," The Scientific World Journal, vol. 2014, pp. 112, 2014.

[7] M. Miranbeigi and H. Iman-Eini, "Hybrid Modulation Technique for Grid-Connected Cascaded Photovoltaic Systems," IEEE Transactions on Industrial Electronics, vol. 63, no. 12, pp. 7843-7853, Dec. 2016.

[8] V. F. M. B. Melo, C. B. Jacobina, N. Rocha, R. P. R. de Sousa, and E. R. Braga-Filho, "Hybrid Dual and NPC SixPhase Drive Systems," IEEE Transactions on Power Electronics, vol. 32, no. 11, pp. 8606-8617, Nov. 2017.

[9] F. Rojas, R. Kennel, R. Cardenas, R. Repenning, J. C. Clare, and M. Diaz, "A New Space-Vector-Modulation Algorithm for a Three-Level Four-Leg NPC Inverter," IEEE Transactions on Energy Conversion, vol. 32, no. 1, pp. 23-35, Mar. 2017.

[10] S. Ojha and A. K. Pandey, "Close Loop V / F Control of Voltage Source Inverter using Sinusoidal PWM , Third Harmonic Injection PWM and Space Vector PWM Method for Induction Motor," vol. 7, no. 1, 2016.

[11] Boualem Boukezata, Abdelmadjid Chaoui, Jean Paul Gaubert et Mabrouk Hachemi "Système solaire photovoltaïque connecté au réseau électrique et associe a un filtre actif parallèle" Symposium de Genie Electrique (SGE’14) : EF-EPF-MGE 2014, 8-10 Juillet 2014, Ens Cachan, France.

[12] T. Hoevenaars, K. Le Doux, and M. Colosino, "Interpreting IEEESTD 519 and meeting its harmonic limits in VFD applications," in Proceedings of the 50th Annual Technical Conference of the Petroleum and Chemical Industry Committee, pp. 145-150,Houston, Tex, USA, September 2003.

[13] E. Babaei, "A cascade Multi-level Converter Topology With Reduced Number of Switches," IEEE Transactions on Power Electronics, vol. 23, no. 6, pp. 2657-2664, November 2008

[14] R.Nagarajan M. Saravanan, "Staircase Multicarrier SPWM Technique for Nine Level Cascaded Inverter," International Conference on Power, Energy and Control (ICPEC), DOI: 10.1109/ICPEC.2013.6527741, (2013).

[15] B.P.Mcgrath, D.G.Holmes, "Multicarrier PWM strategies for multilevel inverters," IEEE Trans. Ind.Electron, vol 49, n.4, pp 858-867,Aug.2002.

[16] M. Sharifzadeh et al., "Hybrid SHM-SHE Pulse-Amplitude Modulation for High-Power Four-Leg Inverter," IEEE Transactions on Industrial Electronics, vol. 63, no. 11, pp. 7234-7242, Nov. 2016.

[17] W. Jiang, S. Du, L. Chang, Y. Zhang, and Q. Zhao, "Hybrid PWM Strategy of SVPWM and VSVPWM for NPC Three-Level Voltage-Source Inverter," IEEE Transactions on Power Electronics, vol. 25, no. 10, pp. 2607-2619, Oct. 2010

[18] J.C.Kartick,B.K.Sujit.K.Suparna,"Dual reference phase shifted pulse with modulation technique for N-Level inverter based grid connected solar photovoltaic system. ," IET Journals \& Magazines Vol.10, Issue:7, pp 928 $935,2016$.

[19] N. Kumar, T. K. Saha, and J. Dey, "Sliding-Mode Control of PWM Dual Inverter-Based Grid-Connected PV System: Modeling and Performance Analysis," IEEE Journal of Emerging and Selected Topics in Power Electronics, vol. 4, no. 2, pp. 435-444, Jun. 2016. 
[20] F. Sebaaly, H. Vahedi, H. Y. Kanaan, N. Moubayed, and K. Al-Haddad, "Design and Implementation of Space Vector Modulation-Based Sliding Mode Control for Grid-Connected 3L-NPC Inverter," IEEE Transactions on Industrial Electronics, vol. 63, no. 12, pp. 7854-7863, Dec. 2016.

[21] D. Jasmine and M. Gopinath, "Hardware implementation of solar based boost to SEPIC converter fed nine level inverter system,” Int. J. Power Electron. Drive Syst., vol. 7, no. 4, pp. 1031-1037, 2016.

[22] Rohit G. Ramteke, U. V. Patil, "Design and comparative study of filters for multilevel inverter for grid interface"978-1-4799-7169-5/14/\$31.00 @2014 IEEE.18

[23] M.Khanfara, R.EL Bachtiri, K.EL Hammoumi, M.Boussetta. "A comparison between two filters for PV inverter controlled to eliminate firsts harmonics" , International Conference on Information Technology for Organizations Development (IT4OD)978-1-4673-7689-1/16/\$31.00 (O2016 IEEE19

[24] B. Nayak, S. S. Dash, and S. Kumar, "Proposed method for shoot-through in three phase ZSI and comparison of different control techniques,” Int. J. Power Electron. Drive Syst., vol. 5, no. 1, pp. 32-44, 2014.

[25] B. Nayak, S. S. Dash, and S. Kumar, "Proposed method for shoot-through in three phase ZSI and comparison of different control techniques," Int. J. Power Electron. Drive Syst., vol. 5, no. 1, pp. 32-44, 2014. 